\title{
KUALITAS MANAJEMEN PADA SAAT PANDEMI COVID 19 DI DESA KEDUNGREJO, DUSUN SAMPANGAN KECAMATAN MUNCAR KABUPATEN BANYUWANGI
}

\author{
Wiwik Fitria Ningsih ${ }^{1}$, Riza AndriyanShidiq ${ }^{2}$, Maria Stefania WaroBheri ${ }^{3}$, Vivy \\ kurniawati dewi ${ }^{4}$, Siskasetyawulandari ${ }^{5}$, Reza Nurhalili ${ }^{6}$, Putri Oktaviana ${ }^{7}$ \\ STIE Mandala Jember ${ }^{1,2,3,4,5,6,7}$ \\ Email: wiwik@stie-mandala.ac.id
}

\begin{abstract}
abstrak
Umkm petis sari ikan tuna ARBA merupakan salah satu Umkm yang berada di Kecamatan Muncar Kabupaten Banyuwangi. Umkm ini bergerak di bidang sumber daya laut lebih tepatnya pemanfaatan Sari ikan tuna yang di produksi oleh pabrik sekitar. Petis sari ikan tuna berbahan baku air rebusan ikan tuna jadi yang di gunakan sebagai petis adalah air uap ikan bukan limbah atau minyak ikan. Banyak program yang bisa kami lakukan di UMKM tersebut sepertihalnya membantu produksi mulai awal hingga petis jadi, selain itu kami juga membantu pengemasan dan pelebelan. Pengemasan yang di gunakan di umkm tersebut ada yg di taruk plastic kecil, botol gelas dan ada juga yang di kemas di timba-timba besar, saat kita melihat logo dari umkm tersebut kurang menarik jadi kita mulai membuatkan logo agar terlihat lebih fresh dan elegan, kami pun membuatkan baner menggantikan baner yang sudah kusam dan rusak, maksud kami melakukan hal ini adalah agar pemasaran semakin meluas banyak yang tau akan umkm petis sari ikan tuna Arba ini melalui sosmed atau pun offline. Umkm tersebut memiliki karawan sebanyak 10 orang, dari 10 orang tersebut ada yang sebagai koki atau peracik, ada yang sebagi pengaduk dan bagian pembungkus bahan yang sudah jadi. Pelanggan dar iproduk petis sari ikan tuna Arba Ini sudah sampai situbondo dan bahkan pemesan banyak yang dari daerah jember.

Kata Kunci: UMKM, Pengembangan, Pemasaran
\end{abstract}

\section{PENDAHULUAN}

Umkm petis sari ikan tuna ARBA merupakan salah satu umkm yang berada di Kecamatan Muncar Kabupaten Banyuwangi. Umkm ini bergerak di bidang sumber daya laut lebih tepatnya pemanfaatan Sari ikan tuna yang di produksi oleh pabrik sekitar. Umkm ini dulu hanya sekedar mencoba-coba untuk membuat sambal petis dalam sekala kecil lambat taun banyak yang menyukai produk ini. Petis sari ikan tuna berbahan baku air rebusan ikan tuna jadi yang di gunakan sebagai petis adalah air uap ikan bukan limbah atau minyak ikan.

Banyak program yang bisa kami lakukan di UMKM tersebut sepertihalnya membantu produksi mulai awal hingga petis jadi, selain itu kami juga membantu pengemasan dan pelebelan. Pengemasan yang di gunakan di umkm tersebut ada yg di taruk plastic kecil, botol gelas dan ada juga yang di kemas di timba-timba besar, saat kita melihat logo dari umkm tersebut kurang menarik jadi kita mulai membuatkan logo agar terlihat lebih fresh dan elegan, kami pun membuatkan baner menggantikan baner yang sudah kusam dan rusak, maksud kami melakukan hal ini adalah agar pemasaran semakin meluas banyak yang tau akan umkm petis sari ikan tuna Arba ini melalui sosmed atau pun offline.

Umkm tersebut memiliki karawan sebanyak 10 orang, dari 10 orang tersebut ada yang sebagai koki atau peracik, ada yang sebagi pengaduk dan bagian 
pembungkus bahan yang sudah jadi. Pelanggan dar iproduk petis sari ikan tuna Arba Ini sudah sampai situbondo dan bahkan pemesan banyak yang dari daerah jember.

Permasalahan Mitra

Di era Pandemi Covid-19 ini sangat berpengaruh bagi kehidupan sehari - hari dan tentunya ekonomi di Indonesia, oleh karna itu kegiatan pengabdian ini berfokus kepada kegiatan Umkm di banyuwangi tepatnya di Umkm Petis Arba kedungrejo Muncar, tujuanya adalah memperdalam kembali informasi mengenai dampak covid-19 di bidang ekonomi dan tentunya sedikit banyak membantu membangkitkan kembali Gairah usaha pada UMKM khususnya UMKM Petis Arba.

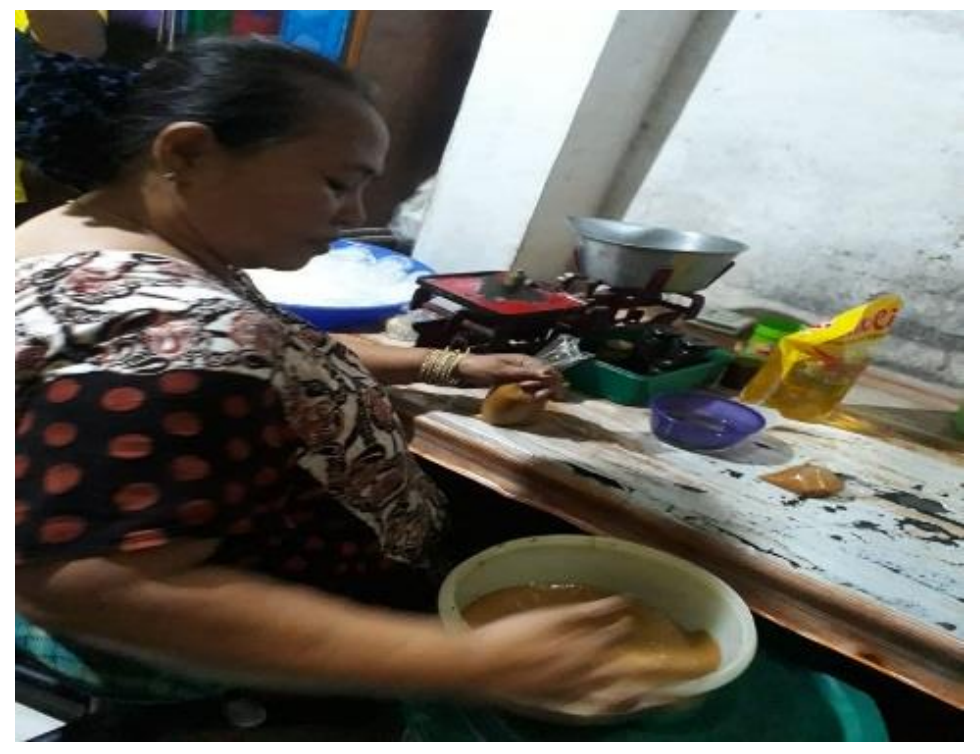

Gambar 1. Pengolahan petis

Dalam menjalankan usaha UMKM sangat tidak mudah, begitu banyak cobaan yang selalu dilewati,dimana kita memulai bisnis dgn hal yg baru,memulai bisnis dari nol sangat sulit,begitu pula yang dialami oleh Pemilik UMKM Petis ARBA.Namun dengan Ketekunan Dan keuletan dari pemilik UMKM petis ARBA sendiri mulai semakin dikenal dan dikagumi oleh banyak masyarakat.Namun dengan adanya Virus corona yang melanda berbagai negara termasuk Indonesia,membuat petis ARBA sedikit tergoncang dalam masalah bahan baku dan pemasaran Offlinenya.Oleh karena itu melalui kegiatan ini kami berkesempatan untuk melakukan Pendampingan pada UMKM Petis ARBA dalam Jangka Waktu 1 bulan Kami berusaha semaksimal mungkin untuk membantu UMKM Petis ARBA,dengan Program kerja kami selama sebulan kami bisa memperbaiki beberapa kendala dalam Proses Petis ARBA. Mulai Dari proses Produksi,Packing,Penentuan Lebel/Stiker pasang Banner dan Proses Pemasaran Offline, karena Petis ARBA sudah banyak digemari dalam luar kota dan lingkungan Banyuwangi, jadi untuk masalah Pemasaran Tidak ada kendala.

\section{METODE PELAKSANAAN}

Mekanisme Pelaksaan tentunya di mulai dari observasi tempat, sosialisasi dan pemahaman progam kerja dan pelaksaan progam kerja, pelaksanaan kegiatan di lakukan selama 1 (satu) bulan yaitu pada bulan agustus 2020. Kegiatan ini didukung penuh oleh pemilik usaha Petis Arba. Kegiatan dilakukan dengan tetap mengikuti protokol kesehatan Covid 19 yaitu menggunakan masker dan menjaga jarak antar masyarakat minimal satu meter. 
Tabel 1. Agenda Kegiatan

\begin{tabular}{|c|c|c|}
\hline NO. & Kegiatan & Keterangan \\
\hline \multirow{3}{*}{1} & \multirow{3}{*}{$\begin{array}{l}\text { Pengenalan Lingkungan UMKM Tempat } \\
\text { KKN }\end{array}$} & $\begin{array}{l}\text { a. Pertemuan dengan } \\
\text { Pemilik UMKM Petis } \\
\text { ARBA }\end{array}$ \\
\hline & & $\begin{array}{l}\text { b. Survei Lokasi UMKM } \\
\text { Petis ARBA }\end{array}$ \\
\hline & & $\begin{array}{l}\text { c. Penjelasan bahan baku } \\
\text { untuk produksi petis } \\
\text { ARBA }\end{array}$ \\
\hline \multirow{3}{*}{2} & \multirow{3}{*}{ Pengenalan Sistematika Proses Produksi } & $\begin{array}{l}\text { a.Pertemuan dengan } \\
\text { pemilik UMKM }\end{array}$ \\
\hline & & $\begin{array}{l}\text { b. Membantu Bagian } \\
\text { Produksi }\end{array}$ \\
\hline & & $\begin{array}{l}\text { c. Membantu Proses } \\
\text { Packing }\end{array}$ \\
\hline \multirow{3}{*}{3} & \multirow{3}{*}{ Pendampingan Proses Produksi\& Packing } & $\begin{array}{l}\text { a.Menyiapkan Bahan } \\
\text { untuk pembuatan petis } \\
\text { ARBA }\end{array}$ \\
\hline & & $\begin{array}{l}\text { b.Mulai membantu Proses } \\
\text { memasak sari Ikan }\end{array}$ \\
\hline & & c. Membantu Packing \\
\hline \multirow[t]{2}{*}{4} & \multirow[t]{2}{*}{$\begin{array}{l}\text { Penyiapan Lebel dan Stiker Untuk Petis } \\
\text { ARBA }\end{array}$} & $\begin{array}{l}\text { a. Diskusi Dengan Pemilik } \\
\text { UMKM mengenai Lebel } \\
\text { baru }\end{array}$ \\
\hline & & b. Penyiapan Lebel \\
\hline \multirow[b]{3}{*}{5} & \multirow{3}{*}{ Membantu Proses Produksi } & a. Rapat Rutin Kelompok \\
\hline & & $\begin{array}{l}\text { b. Berbincang bincang } \\
\text { dengan pemilik UMKM }\end{array}$ \\
\hline & & $\begin{array}{l}\text { c. Pertemuan dengan } \\
\text { Dosen Pembimbing }\end{array}$ \\
\hline 6 & PendampinganPemasaran Offline & a. Penjualan offline \\
\hline \multirow[b]{2}{*}{7} & \multirow[b]{2}{*}{ Membantu Proses Produksi } & $\begin{array}{l}\text { a. Membantu Proses } \\
\text { Produksi dan Packing }\end{array}$ \\
\hline & & $\begin{array}{l}\text { b. Penataan layout } \\
\text { UMKM }\end{array}$ \\
\hline
\end{tabular}




\section{HASIL DAN PEMBAHASAN}

Selama masa perencanaan program KKN, kami tidak banyak kegiatan yang di persiapkan untuk di laksanakan di UMKM petis sari ikan tuna ARBA, hal ini dikarnakan sudah siapnya produk yang ada akan tetapi ada beberapa hal yang belum ada dan itu menjadi tujuan kita. Kami sebelum berangkat KKN hanya merencanakan sedikit kegiatan selanjutnya kami melihat kondisi di umkm saat itu.

Program-program yang kami rencanakan dalam kegiatan KKn sudah melalui proses observasi tentang kemampuan mahasiswa dan kebutuhan umkm yang harus kita lakukan.

Adapunkegiatan yang telah kami laksanakanadalahsebagaiberikut :

1. Pembaharuan media pemasaran yang ada di umkm tersebut di antaranya adalah pembuatan baner yang sudah rusak di depan umkm menjadi lebih menarik, dengan itu semua orang bias melihat baner tersebut dan mengetahui produk tersebut.

Ada pun media yang ke 2 adalah sosmed, di situ kami memfoto produk agar lebih menarik untuk di pasang di sosmed.

2. Membantu bagian produksi agar karyawan lebih riangan pekerjaannya, karna di dalam produksi ini kami menghadapi panasnya api pembakaran dan petis yang sudah masak untuk di aduk hingga jadi.

3. Kami perbarui logo lama menjadi logo yang modern dan elegan. Karna logo lama kurang menarik dengan kondisi sekarang ini, dan pemilik UMKM pun bersedia logonya kami perbarui. Dan hasilnya kami meberikan logo yang terbaru simple dan sangat modern.

\section{FAKTOR PENDUKUNG DAN PENGHAMBAT}

\section{a. FAKTOR PENDUKUNG}

beberapa factor pendukung pelaksanaan program kami yaitu :

- Kami mendapatkan respon baik dari pemilik UMKM dan karyawan yang ada di sana.

- Kami juga di berimasukan oleh pemilik UMKM bagaimana cara memasarkan produkbahkan memulai sebuah usaha, sehingga kami tau apa yang harus di lakukan untuk mengisi kekosongan umkm dengan program kami.

- Karyawan semua juga sangat antusias membantu kami dalam

\section{b. FAKTOR PENGHAMBAT} menjalankan program yang sudah di siapkan oleh mahasiswa.

Dalam melakukan kegiatan selain mendapatkan factor pendukung, kami pun mendapatkan hanbatan selama KKN yaitu :

- Kami tidak bias menjalankan program yang ada secara sempurna di karnakan tebatasnya waktu serta adanya pandemic covid-19.

- Terbatasnya dana yang ada sehingga kami harus memikirkan semua pengeluaran dalam menjalankan program untuk UMKM tersebut.

\section{Keberlanjutan Program}

Berdasarkan program kegiatan yang kami laksanakan selama satu bulan ini, ada beberapa program yang bisa di tindaklanjuti seperti pemasaran online di sosial media. Dengan cara selalu aktif dan memposting foto-foto baru sehingga palanggan menjadi aktif mengunjungi akun sosmed UMKM. 


\section{KESIMPULAN}

UMKM Petis ARBA sangat berpotensi Bagus dalam bidang wirausaha,Lokasi Bahan baku yang diperoleh juga tidak mempersulit proses produksi petis ARBA,karena lokasinya Petis ARBA sangat dekat dengan Lokasi Penghasil Sari Ikan.Petis ARBA Juga sudah banyak dikenal dikalangan Masyarakat Desa muncar,Banyuwangi Bahkan Luar kota Banyuwangi.Packing Petis ARBA juga sangat menarik Customer,ada packing kecil,menengah sampai yg packing besar.Pada saat kami melakukan kuliah kerja nyata di UMKM Petis ARBA,Kesulitannya karena Bahan Bahan yang berubah misalnya harga Gula pasir,Harga sari ikan,Cuman masih bisa diatasi Oleh Pemilik UMKM.

\section{DAFTAR PUSTAKA}

Naviah, Siti. 2020. PKM-Mekanisasi Produksi Petis Udang Di UD Murni Sidoarjo. Penamas Adi Buana, 04(1), 33-36.

Sari, Dkk. 2015. Pembuatan Petis Instan (Kajian Jenis Dan Proporsi Bahan Pengisi). Pembuatan Petis Instan, 03(2), 381-389.

Riski. (2016, November 11). Raih Untung Dari Usaha Rujak Buah Dan Petisan. Berwirausaha. Di akses pada 30 Juli 2020 melalui

https://www.berwirausaha.net/2016/11/peluang-usaha-rujak-buah-ataupetisan.html\% $2 \mathrm{Fn}$ 